Dialectologia. Special issue, V (2015), 109-140.

ISSN: 2013-2247

Received 9 August 2015.

Accepted 1 October 2015.

\title{
CONDITIONAL SENTENCES IN THE ALPI. A CONTRASTIVE ANALYSIS OF THE PENINSULAR NORTHWEST ${ }^{1}$
}

\author{
Rosa Mouzo Villar \& Carolina Pérez Capelo \\ Instituto da Lingua Galega - Universidade de Santiago de Compostela \\ rosa.mouzo@usc.es / carolina.perez.capelo@usc.es
}

\begin{abstract}
In the field of syntax, conditional sentences were the research focus of many studies concentrating upon different aspects of such constructions: structure, tenses used in protasis and apodosis, etc. (Xove 1986; Veiga 1991). Some of these studies have examined the peculiarities which occur in conditionals according to the linguistic territory occupied by them. By taking into account these previous works, the objective of this present study is to analyse conditional sentences in the different Romance languages which converge in the Iberian Peninsula (Galician, Portuguese, Astur-Leonese and Castilian). The different tenses present in the protasis and apodosis of these sentences will be the chief focus of this study, which will examine the most frequent in each language and observe whether there is some kind of dialectal distribution or not. The basis for this will be the data provided by the Atlas Lingüístico de la Península Ibérica $(A L P I)$ and the three conditional sentences featured in this atlas will form the core of the present analysis.
\end{abstract}

\section{Keywords}

conditional sentences, Atlas Lingüístico de la Península Ibérica, protasis, apodos

\section{AS ORACIÓNS CONDICIONAIS NO ALPI. UNHA ANÁLISE CONTRASTIVA DO NOROESTE PENINSULAR} Resumen

No eido da sintaxe, as oracións condicionais foron obxecto de investigación de múltiples estudos centrados en diferentes aspectos destas construcións: estrutura, tempos verbais usados na prótase e na

\footnotetext{
${ }^{1}$ This work has been supported by the Xunta de Galicia (Consellería de Cultura, Educación e Ordenación Universitaria) and the European Union (under grant code GRC2013/40).
} 
apódose, etc. (Xove 1986; Veiga 1991). Algúns deses traballos téñense fixado nas peculiaridades que presentan as condicionais segundo o territorio lingüístico que ocupan. Tendo en conta estes estudos previos, desenvolvemos este traballo que ten como obxectivo analizar as oracións condicionais nas diferentes linguas románicas que conflúen no noroeste da Península Ibérica (galego, portugués, asturleonés e castelán). Principalmente ocuparémonos dos diferentes tempos verbais presentes na prótase e na apódose destas oracións, examinando cales son os máis frecuentes en cada lingua e observando se se dá ou non algún tipo de distribución dialectal. No noso estudo partimos dos datos que nos proporciona o Atlas Lingüístico de la Península lbérica $(A L P I)$ e centrámonos nas tres oracións condicionais que foron recollidas neste atlas.

\section{Palabras chave}

oracións condicionais, Atlas Lingüístico de la Península Ibérica, prótase, apódose

\section{Introduction}

The Atlas Lingüístico de la Península Ibérica $(A L P I)$ has generated a broad series of studies in recent years related to different areas of linguistics. In spite of its data being collected during the first half of the 20th century, the ALPI continues to cause an impression today because of the modernity of its questionnaire, precisely as David Heap observes (2002: 13). Heap also points out that it is an atlas which provides extensive information that allows for the undertaking of phonetic and lexical studies (the favourite studies of geolinguistics), and also morphosyntatic studies, on account of the numerous questions registered in Notebook I regarding unstressed pronouns, different verb forms, constructions with the impersonal 'se', passive reflexive sentences or conditional sentences, which are the subject of this study.

This is the reason why for this present work the data which this atlas offers is taken as a basis to analyse the structures of conditional sentences in the linguistic varieties of the northwest of the Peninsular Northwest. The three conditional sentences which are included in Notebook I, in the section on morphosyntaxis, are considered:

386. Si tuviera dinero lo compraría [If I/he/she had money, I/he/she would buy it] 387. Si estudiase aprendería [If I/he/she studied, I/he/she would learn] 
388. Si pudiera la mataría [If I/he/she could, I/he/she would kill her]

This study will focus upon the syntatical structure presented by these sentences in each linguistic area of the Peninsular Northwest, as well as the tense-mode morphemes (TMM) of the verb forms which constitute them, in order to determine if these features present or not a dialectal distribution in the territory under examination.

\section{1. $A L P I$}

In 1914 Ramón Menéndez Pidal conceived the idea of developing a linguistic atlas in order to study the Romance varieties of the Iberian Peninsula. In order to coordinate this project, Menéndez Pidal chose his disciple, Tomás Navarro Tomás, who undertook the selection and supervision of the group of interviewers who would attend to the collection of materials in the selected points of the principal linguistic areas:

- Aníbal Otero, Rodrigo de Sá Nogueira, Armando Nobre de Gusmão and L. F. Lindley Cintra: Galician and Portuguese areas

- Aurelio M. Espinosa and Lorenzo Rodríguez Castellano: Castilian area

- Francesc de Borja Moll and Manuel Sanchis Guarner: Catalan, Valencian and Balear areas.

The researchers began the data collection from $1931,{ }^{2}$ but in 1936 , with the outbreak of Civil War, the collection work was interrupted and left incomplete in Asturias, Cataluña, Valencia and Portugal; these were finished in their majority between 1947 and $1954^{3}$ (Sousa 2010: 243-244).

The ALPI sought to be an exceptionally knowledgeable atlas, similar to those which were being produced at that time in Central Europe (Pedrazuela 2005: 274); what was being sought was not a detailed vision of the territory, but "unha visión de

\footnotetext{
2 "La primera salida la realizó Espinosa en la primavera de 1931 por pueblos de Cáceres", in Pedrazuela 2005: 280. "The first excursion was undertaken by Espinosa in the spring of 1931 throughout towns in Cáceres."

${ }^{3}$ In some Portuguese locations the fieldwork was not completely finished until the summer of 1956 (ALPI 1962).
} 
conxunto que definise as grandes liñas e mesmo as características dos principais dominios" (Álvarez 2014: 179). ${ }^{4}$ The locations network was made up of 528 locations and the informants were selected carefully in order that they be the best representatives of local speech:

Tenían que ser naturales del pueblo estudiado, y se procuraba que también lo fuesen sus padres y esposas. Eran preferidos los que habían viajado poco y no habían residido fuera del lugar, y también los analfabetos o muy poco instruídos, a fin de que se viesen exentos de la influencia de los dialectos de otras localidades y de la lengua culta (ALPI 1962). ${ }^{5}$

The ALPI questionnaire was divided in two notebooks for the gathering of material: I, Phonetics, Morphology and Syntax, in which the questions employed for this study are included, and II, Lexicon and Ethnography. ${ }^{6}$

At the time when the notebook enquiry was designed, Navarro Tomás was carrying out research in phonetics abroad, and this can be seen reflected in the questionnaire by the largest number of questions related to this discipline, by the care when designing a complex phonetic alphabet and by taking the trouble to provide efficient collection tools (Pedrazuela 2005). However, although the less syntax questions were scarcer, they also allow us to carry out studies such as this.

\subsection{Territory studied}

In this work the space examined in the ALPI is limited, and focus is placed solely on locations in Portugal and the northwest of the Spanish state, on the territory comprised by Galicia, Asturias and the Castilian provinces of León, Zamora and

\footnotetext{
4 "A vision of the whole which might define the main lines and even the characteristics of the principal domains."

${ }^{5}$ They had to be natives of the town being studied, and it was also the intention that their parents and partners were too. Those people who had travelled little and had not resided elsewhere, and also the illiterate and little educated were preferred, with the objective of them being exempt from the influence of the dialects of other locations and of the learned language (ALPI 1962).

${ }^{6}$ Two versions of this second notebook were produced: an abbreviated version, the IIG, with 417 questions, and another more extensive version, the IIE, with 833 questions, which was the most employed.
} 
Dialectologia. Special issue, V (2015), 109-140.

ISSN: 2013-2247

Salamanca. In this study's annex Maps (3) and (4) and the list of places where the enquiry was carried out in this territory are included, with codes used in the ALPI. The locations network studied is what is schematically included in Chart 1.

\begin{tabular}{|c|c|}
\hline GALICIA & 52 LOCATIONS $(100-151)$ \\
\hline A Coruña & 15 locations (100-113) \\
\hline Lugo & 14 locations (114-127) \\
\hline Pontevedra & 13 locations (128-140) \\
\hline Ourense & 11 locations (141-151) \\
\hline PORTUGAL & 93 LOCATIONS (200 - 292) \\
\hline Viana do Castelo & 5 locations (200-204) \\
\hline Braga & 7 locations (205-211) \\
\hline Oporto & 5 locations (212-216) \\
\hline Vila Real & 3 locations (217-219) \\
\hline Bragança & 9 locations (220-228) \\
\hline Guarda & 6 locations (229-234) \\
\hline Viseu & 6 locations (235-240) \\
\hline Aveiro & 3 locations (241-243) \\
\hline Coimbra & 5 locations (244-248) \\
\hline Castelo Branco & 6 locations (249-254) \\
\hline Leiria & 4 locations (255-258) \\
\hline Santarem & 7 locations (256-265) \\
\hline Portalegre & 6 locations (266-271) \\
\hline Lisbon & 4 locations (272-275) \\
\hline Setúbal & 3 locations (276-278) \\
\hline Évora & 2 locations (279-280) \\
\hline Beja & 6 locations (281-286) \\
\hline Faro & 6 locations (287-293) \\
\hline ASTURIAS & 24 LOCATIONS (300 - 323) \\
\hline LEÓN & 13 LOCATIONS (324 - 336) \\
\hline ZAMORA & 12 LOCATIONS (337 - 348) \\
\hline SALAMANCA & 11 LOCATIONS (349 - 359) \\
\hline
\end{tabular}

Chart 1. Territory studied

Four linguistic domains converge in the area studied: Galician, Portuguese, AsturLeonese and Castilian. As is well known, these do not coincide with the administrative 
territorial divisions. In Chart 2, the locations belonging to each one of the domains is specified. $^{7}$

\begin{tabular}{|l|l|l|}
\hline Galician & 61 locations & Galicia (52 locations) + Asturias (5) + León (2) + Zamora (2) \\
\hline Portuguese & 92 locations & Portugal (92) \\
\hline Astur-Leonese & 31 locations & Asturias (19) + León (6) + Zamora (5) + Portugal (1) \\
\hline Castilian & 21 locations & León (4) + Zamora (5) + Salamanca (11) \\
\hline
\end{tabular}

Chart 2. Linguistic domains ${ }^{8}$

\section{Corpus analysis}

In order to carry out this study, such as is conveyed in the introduction, the conditional sentences included in Notebook 1 of the $A L P I$, in the Morphosyntaxis section, are employed. It should be taken into account that, as De Benito (2010: 4) points out:

\section{El estudio de variables sintácticas en un atlas lingüístico presenta diversas dificultades (...) resulta difícil aislar en el cuestionario los múltiples factores que pueden influír en la variación (...) se pretendía elicitar la misma oración de todos los informantes, los primeros atlas recurrían a la pregunta directa y les pedían que repitiesen la oración, lo que puede haber influído decisivamente, y de forma difícil de valorar, en el comportamiento lingüístico del informante. En las zonas bilingües especialmente, la actitud del encuestador puede haber sido determinante a la hora de elegir el modelo lingüístico en el que se formuló la pregunta (castellano, gallego, catalán, etc.), por lo que no podemos tener la certeza de si los datos obtenidos son representativos de la situación dialectal o si se trata de una imitación del modelo propuesto. ${ }^{9}$}

\footnotetext{
7 It is not always straightforward to ascribe specific diatopic varieties to one or another linguistic domains, especially when it concerns border varieties. When establishing the distribution of locations studied by domain, the works of Babarro (2003), Seco Orosa (2001) and Morala Rodríguez (2001) were considered.

${ }^{8}$ In the table of locations found in the annexe, the linguistic domain to which each one of the enquiry locations is ascribed is included.

${ }^{9}$ Sections in bold have been highlighted by the authors of this article. "The study of syntactical varieties in a linguistic atlas presents different difficulties. (...) It is difficult to isolate in the questionnaire the
} 
Therefore, the variety of responses that we find in structures used in conditional sentences or the alternation which the TMM present could be on account of dialectal variation, but also of different factors which influenced data collections, in accordance with De Benito. However, as has already been indicated, as the territory studied is an area of linguistic convergence, linguistic interference can occur. This study will seek to analyze such issues.

The analysis that is put forward presently regarding the data obtained from the $A L P I$ is organized in the following manner:

Firstly, the structures registered for each sentence in each linguistic area is analyzed by focussing upon the variants encountered: their frequency, their predominant structures, etc. This will allow the establishing of a comparison of the results between the different varieties.

Secondly, these structures are examined in the most detailed manner, and by focussing on the one hand on the protasis analysis, and on the other hand on that of the apodosis. In this case, the three sentences are dealt with collectively, with attention paid to verb tenses and the TMM which appear in each one of the clauses in the different linguistic domains.

\subsection{Sentences. Structure}

As Álvarez \& Xove (2002: 156) indicate: “na construción condicional establécese que os feitos narrados nunha oración (apódose) ocorren ou ocorrerían de se cumpri-la hipótese ou condición expresa na oración que leva o nexo (prótase)". ${ }^{10}$ These

multiple factors which can influence variation (...). The aim was to elicit the same sentence from all the informants; the first atlases resorted to the direct question and asked them if they would repeat the sentence, which might have been a decisive influence, and in a way that is difficult to evaluate, upon the linguistic behaviour of the informant. In bilingual areas especially, the attitude of the interviewer might have been decisive when choosing the linguistic model through which the question was formulated (Castilian, Galician, Catalan, etc.). As such, we cannot be certain as to whether the data obtained is representative of the dialectal situation or if it is a matter of an imitation of the proposed model."

10 "In the conditional construction, it is established that the events narrated in a sentence (apodosis) occur or would occur if the hypothesis or condition expressed in the sentence which carries the nexus (protasis) came to happen." 
characteristics are shared by the languages of the Peninsular Northwest. Therefore, the basic structure of the conditionals of the $A L P I$ is the same in all the questions analyzed: se + protasis + apodosis, although in these clauses different combinations of verb tenses are found and will be described presently.

2.1.1. Si tuviera dinero lo compraría [If I/he/she had money, I/he/she would buy it]

\subsubsection{Galician}

The majority structure registered in Galician in this first conditional sentence is that formed by tivera + compraría (Se tivera diñeiro compraríao), which is ground in 39 locations surveyed. In the remaining 22 , the structure registered was that formed by tivera + comprábao (Se tivera diñeiro comprábao). In this case, a clear distribution does not exist. Instead, the two structures appear distributed throughout the entire Galician area.

\subsubsection{Portuguese}

The conditional pattern registered practically throughout the entire Portuguese area is that formed by tivesse + comprava (Se (eu) tivesse dinheiro, comprava-o), with 88 examples scattered throughout the entire territory. Other, less frequent structures are registered, like tivera + comprava (Se tivera dinheiro comprava-o), logged in the localities of Montemor-o-Velho (245), Almeirim (264) and Rio de Onor (222); tivesse + compraria (Se tivesse dinheiro compraria-o), collected only in the location of Atouguia da Baleia (258) and, finally, tiver(e) + compraria, a structure registered only in Pataias (256): Se tiver dinheiro comprava-o.

\subsubsection{Astur-Leonese}

In the Astur-Leonese domain, the most frequent structure is tuviera + compraba (Si tuviera dineru comprábalu), registered in practically the entirety of the survey 
locations. In the Asturian locality of Felechosa (315), in the county Ayer, a different structure for this sentence is found: tuviera + compraría (Si tuviera cuartus compraríalu). In the Portuguese location of Duas Igrejas (225), Miranda Do Douro (Bragança), the structure tivesse + comprava (Se tivesse dinheiro comprava-lo) appears.

\subsubsection{Castilian}

In the locations pertaining to the Castilian area, three different structures are registered: tuviera + compraba, tuviera + compraría e tuviera + comprara. The first of them (Si tuviera dinero lo compraba) is the most frequent, found in 11 of the 21 locations within this domain. The construction tuviera + compraría (Si yo tuviera dinero lo compraría), registered in 8 localities, is also common. Finally, the last of the structures (Si tuviera dinero lo comprara) is very uncommon, ocurring solely in the localities of Fuenteguinaldo (357) and Retortillo (353), both in Salamanca.

\subsubsection{Si estudiase aprendería [If $\mathrm{I} / \mathrm{he} / \mathrm{she}$ studied, $\mathrm{l} / \mathrm{he} / \mathrm{she}$ would learn]}

\subsubsection{Galician}

With this second conditional sentence, in the Galician domain, we find three different structures: estudara + aprendería, estudara + aprendía, estudase + aprendería. The most common is the first of them (Se estudara aprendería), registered in 41 locations. The response Se estudara aprendía is also relatively frequent, being collected in 13 of the surveyed locations. Finally, Se estudase aprendería is registered in 7 locations of the domain.

\subsubsection{Portuguese}

The majority structure in the Portuguese area is that formed by estudasse + aprendia (Se estudasse aprendia), with 90 examples distributed throughout the entire 
territory. In just two locations, in Moita (276) and in Barrancos (281), a different response is registered: (Se) estudasse + aprenderia .

\subsubsection{Astur-Leonese}

With Astur-Leonese the majority response to this question is Si estudiara aprendía. This structure (estudiara + aprendía) is registered in 20 of the 31 locations in the domain. The structure estudiara + aprendería (Si estudiara aprendería) is also found, although with less frequency, in 6 localities. In the locations of Páramo del Sil (326) and Pontedo (330), both in León, and also in Mahide (343), in Zamora, another different structure is obtained: estudiara + aprendiera (si estudiara aprendiera). Finally, registered in the Asturian locality of Busmente (304) are estudiase + aprendería (Si estudiase aprendería), and in the Portuguese locality of Duas Igrejas (225), estudasse + adeprendia (Se estudasse adeprendia).

\subsubsection{Castilian}

The majority pattern in the Castilian domain is estudiara + aprendería ( $\mathrm{Si}$ estudiara aprendería), registered in 12 locations. The structure estudiara + aprendía (Si estudiara aprendía), which is collected in 8 places, is also frequent. In the locality of Folledo (329), in León, the response was: estudiara + aprendiera (Si estudiara aprendiera).

\subsubsection{Si pudiera la mataría [If $\mathrm{I} / \mathrm{he} /$ she could, $\mathrm{I} / \mathrm{he} / \mathrm{she}$ would kill her]}

\subsubsection{Galician}

In the responses to the third question, the two structures poidera + mataría and poidera + mataba are found in the Galician domain. The first of them (Se poidera mataría) is the most frequent, with 39 examples distributed throughout the entire 
Dialectologia. Special issue, $\boldsymbol{V}$ (2015), 109-140.

ISSN: 2013-2247

territory. The second (Se poidera matábaa) is also common, being registered in 22 localities distributed through the whole of the Galician area.

\subsubsection{Portuguese}

The most frequent structure in Portuguese, again with considerable difference, is that formed by pudesse + matava (Se pudesse matava-a), with 91 examples, of which one, which appears in Ferreira do Alentejo (283), presents the clauses in reverse: Matava-a se pudesse. The only location in which this structure does not appear is that of Rio de Onor (221), where (Se) + pudiera + matava-a is registered.

\subsubsection{Astur-Leonese}

In practically the entirety of the locations in the Astur-Leonese domain, the structure pudiera + mataba (Si pudiera, matábala) is found. The other existing patterns are registered only in each of the following locations: Felechosa (315), in the county of Ayer (Asturias), pudiera + mataría (Si pudiera, mataríala) and in the Portuguese locality of Duas Igrejas (225), Bragança, pudesse + mataba (Se pudesse matábala).

\subsubsection{Castilian}

Finally, in the Castilian area, the most frequent structure is also pudiera + mataba (Si pudiera la mataba), registered in 17 of the 21 domain locations. In three localities of Salamanca (350 -Guijuelo del Barro-, 355 -Serradilla del Arroyo- and 359Valdefuentes de Sangusín-) pudiera + mataría (Si pudiera la mataría) is found. In location 329 (Folledo, León), the response registered is Si pudiera la matara, with the structure pudiera + matara.

\subsection{Verb tenses in the protasis}

The TMM employed in the protasis present an alternation and clear distribution throughout the territory studied in this work, as can be seen in Map 1. 
The granite colour, which represents the TMM -ra, is extended throughout the Galician, Astur-Leonese and Castilian area, and the linguistic limits in this case coincide with the administrative ones in regard to the Portuguese area, where the TMM -sse, represented by the colour blue, is clearly dominant, it being the only one registered in 90 of the 92 locations surveyed in the area of Portuguese speech. This question will now be analyzed in more precise details in each linguistic domain. Título del mapa en inglés?

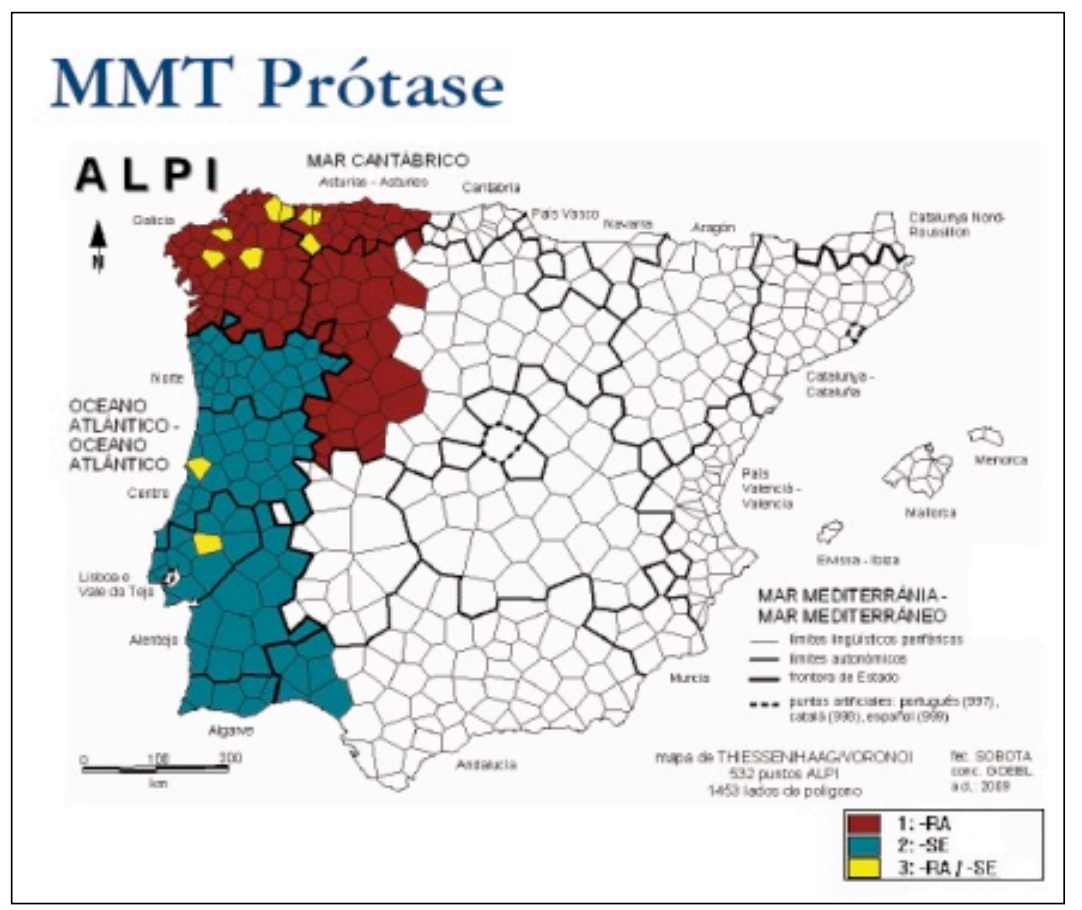

Map 1. MMT Protasis

\subsubsection{Galician}

According to Álvarez \& Xove (2002: 156), in Galician the most characteristic conditional pattern is that which uses the conjunction se as a nexus in the protasis. The verb is in the indicative when the mood is non-irreal and in the past subjunctive if it is irreal, as occurs in the constructions registered in the ALPI in the Galician area. Xove (1992: 150) indicates that: 
Dialectologia. Special issue, $\boldsymbol{V}$ (2015), 109-140.

ISSN: 2013-2247

Desde o punto de vista do falante, este pode ter experiencia ou coñecemento efectivo da súa irrealidade ou pode dalos como tales aínda carecendo de datos seguros sobre a súa existencia. É dicir, un falante pode dar como irreais acontecementos que empiricamente poden revelarse non irreais (se viñese mañá poderiamos saír xuntos é irreal aínda que a persoa en cuestión "chegue mañá", do mesmo modo que virá mañá é plenamente real aínda que ó cabo resulte a súa incomparecencia). (...) a creación expresa [das situacións inexistentes] (...) realízase necesariamente con andara ou andase. ${ }^{11}$

The past subjunctive in Galician presents two variants of the TMM, -ra e -se, and according to Xove (1986: 135-136):

... a frecuencia relativa de -ra e -se depende basicamente de se existe ou non significado irreal. En presencia deste, a proporción de -ra sobe enormemente e de xeito regular. (...) O escaso número do -se irreal (...) aparece distribuído polas distintas áreas xeográficas. é dicir, as porcentaxes non sofren modificacións en relación coas variedades dialectais. ${ }^{12}$

Therefore, the TMM registered in Galician in the protasis of the three conditional constructions which appear in the $A L P I$ is the $-r a$ of the past subjunctive, and coinciding with what Xove indicates, is what is mainly recorded, since in 7 locations of those in which -se was found, which was only in the responses of the second conditional construction, -ra appears in the other two questions in these same localities.

\footnotetext{
11 "From the speaker's point of view, they can have an effective experience or knowledge of their irreality or can provide these as such even when secure data regarding their existence is lacking. That is to say, a speaker can interpret as irreal those events which can be revealed empirically as non-irreal (se viñese mañá poderiamos saír xuntos is irreal, even though the person in question "chegue mañá" or arrives tomorrow, in the same way that virá mañá is wholly real even though in the end there is a nonappearance). (...) The express creation [of inexistent situations] (...) is realized necessarily by andara or andase."

12 "The relative frequency of -ra and -se depends basically on whether there exists or not an irreal meaning. If it is the latter case, the proportion of -ra increases enormously and in a regular manner. (...) The scarce number of irreal -se (...) appears distributed through the different geographical areas. That is, the percentages do not undergo modifications in relation to the dialectic varieties."
} 
Furthermore, the form -se, just as Xove also underlines, does not present a dialectic distribution, but appears spread out across 7 localities in the Galician speech area: 2 in the A Coruña province (Abegondo -104- and Lavacolla -112-), 3 in that of Lugo (Ferreira do Valadouro -116-, A Devesa -117- and Palas de Rei -121-) and the remaining 2 were collected in Asturian administrative territory (Freal, in Navia -302-, and Cuantas, in Ibias -323-).

Therefore, the variant - $r a$ is, with considerable difference, the most frequent in the Galician area, occurring in $96.17 \%$ of cases, whilst the use of -se is reduced to $3.82 \%$. The data registered in the ALPI corroborate what has been pointed out by Xove (1981) and by Álvarez \& Xove (2002), since the variant -ra "tende a se-la máis frecuente co significado de irrealidade" ${ }^{13}$

\subsubsection{Portuguese}

In the Portuguese area, protasis presents the TMM of the pretérito do conjuntivo -sse [copretérito de subxuntivo] ${ }^{14}$ in practically all registered responses, in $98.18 \%$ of cases. The exceptions, which constitute the remaining $2.17 \%$, are found in just 4 localities. In 2 of them, Montemor-o-Velho (245) and in Almeirim (264), the TMM of the pretérito mais-que-perfeito -ra [antepretérito de indicativo] was registered only in the first conditional (Si tuviera dinero lo compraría) and the TMM of the copretérito de conjuntivo -se in the other cases. In Rio de Onor (221), the TMM -ra was registered in the responses to three questions. Finally, in Pataias (256) a register of the form $-r(e)$ is found, which is possibly a futuro de conjuntivo with a paragogic (e).

The Portuguese grammars consulted (Cintra \& Cunha 2000 and Mira Mateus 2003) insist upon the use of the conjuntivo in conditional sentences: "o conjuntivo é por excelência o modo da oração subordinada (...) Usa-se nas orações condicionais, em que a condição é irrealizável ou hipotética" (Cintra \& Cunha 2000: 466-469). ${ }^{15}$ Therefore, it is strange to find these three cases in which the pretérito mais-que-

\footnotetext{
13 "Tends to the most frequent with the meaning of irreality."

${ }^{14}$ The equivalent tenses in Galician are indicated in brackets.

15 "The subjunctive is the mode par excellence of the subordinate clause (...). It is used in conditional sentences, in which the condition is impossible or hypothetical."
} 
perfeito de indicativo is registered. In a preceding work (Mouzo 2009: 593), it is suggested that:

\begin{abstract}
O que puido ocorrer é que, ou ben exclusivamente nesta zona se usa o pretérito mais-que- perfeito de Indicativo con valor de pretérito de conjuntivo, ou ben se comparta esta forma en común co copretérito de subxuntivo do galego (tivera/tivese), pois sendo linguas irmás, da mesma maneira que comparten trazos fonéticos tamén os comparten morfosintácticos. ${ }^{16}$
\end{abstract}

In this case, when taking into account more data and also observing what takes place in other domains, the first hypothesis is regarded as being more accurate, because the informants answered "tivera" as the first response and "tivesse" as the second, and therefore this TMM -ra is not unknown to them. Moreover, as De Benito points out (vide supra), it could have also influenced the "imitation of the model proposed" by interviewers.

\title{
2.2.3. Astur-Leonese
}

In the Astur-Leonese variety, as the Gramática de la Llingua Asturiana (ALLA 2001) [Grammar of the Asturian Language] indicates, the tense that is employed in the protasis of conditional sentences is the pretérito imperfeutu de suxuntivu [copretérito de subxuntivo]: “amuesa [pretérito imperfeutu de suxuntivu] conteíos como'l de deséu (quería que lo ficiera, oxalá lo ficiera) o - equivaliendo al condicional - el de probabilidá futura nel pasáu (cantara una tonada si pudiera)" ${ }^{17}$

This TMM is what was registered in practically all the localities surveyed in the Astur-Leonese territory included in this study, in $95.69 \%$ of cases. In the remaining 4.30\% the TMM -se is employed, in Busmente (304, Villayón - Asturias) and in Duas

\footnotetext{
16 "What could have occurred is that either exclusively in this region the pretérito mais-que-perfeito de Indicativo is used in the same way as the pretérito de conjuntivo, or this form is shared in common with the copretérito de subxuntivo of Galician (tivera/tivese), since as they are sister languages, they share phonetic features in the same way as they share morphosynatic ones."

17 "It shows [pretérito imperfeutu de suxuntivu] contexts such as that of desire (quería que lo ficiera, oxalá lo ficiera) or - equaling the conditional - that of future probability in the past (cantara una tonada si pudiera)."
} 
Igrejas (221, Bragança - Portugal). In the Asturian locality a register of the TMM -se, which the informant gave as a response to the second question (Si estudiase aprendería) was collected. This TMM does not belong to the verb paradigm of Asturian, and therefore in the same manner as occurred in the Portuguese domain, this is a case which merits attention. If the questions of the atlas are analysed, it can be seen that this second question is formulated with the TMM -se in Spanish:

\section{Si estudiase aprendería}

Therefore, in the same way as what occurred in the Portuguese case with the form - $r a$, the variant -se that was registered in this Asturian locality was produced through imitation of the interviewers. Moreover, as it is the only response and the informant did not answer "estudiara" as a second response, it seems that they were not unaware of the form estudiase, which they could know through Galician or Castilian, given that Busmente is a border locality. In the location of Duas Igrejas, the TMM -sse was registered as a response to three conditional sentences, but it would seem that the explanation in this case can be found in the influence of Portuguese.

\subsubsection{Castilian}

In Castilian, as with the other languages of the northwest of the Iberian peninsula that have been so far considered, in the protasis of conditional sentences of this kind the pretérito imperfecto de subjuntivo [copretérito de subxuntivo] is used. This tense presents, in the same manner as Galician, the variants -ra and -se, but in conditional contexts -ra is employed with greater frequency:

La sustitución de amārem por amavissem empezó a darse en contextos modales, en especial condicionales, lo que anticipaba el importante cambio gramatical que CANTARA experimentó en la historia del español (RAE 2009: 1803). ${ }^{18}$

\footnotetext{
18 "The substitution of amārem for amavissem began to occur in modal contexts, under special conditions, which anticipated the important grammatical change which CANTARA underwent in the history of Spanish" (RAE 2009: 1803).
} 
Dialectologia. Special issue, V (2015), 109-140.

ISSN: 2013-2247

Although at first the forms -ra and -se can be used indistinctly because of their grammatical equivalence, the grammars consulted (RAE 1999; RAE 2009) indicate that the form -ra is the most employed:

En el estado actual de la lengua la forma en -ra siempre admite ser empleada como equivalente de la forma en -se, y si lo contrario no es posible en todos los casos para la forma simple cantase, la razón no es otra que la conservación por parte de cantara de algunos empleos modalmente indicativos, pervivencias de su valor etimológico. Sin embargo, como expresiones del contenido modal propio del subjuntivo, las formas en -ra y en -se son hoy por hoy perfectamente equivalentes, con lo que tenemos que señalar la existencia de dos realizaciones expresivas concretas en relación de alomorfismo (...). La reducción en el uso de una de estas formas a favor de la otra en la lengua hablada es, con toda probabilidad, uno de los factores que han motivado en algunos autores querer ver diferencias de matiz significativo entre cantara y cantase, diferencias completamente imaginarias de acuerdo con el funcionamiento del sistema verbal español actual (RAE, 1999: 2910). ${ }^{19}$

Indeed, in the localities surveyed in the ALPI within the Castilian area, situated in the provinces of León, Salamanca and Zamora, only the -ra form was registered in $100 \%$ of cases in the responses collected, which reasserts the reduction of the -se form with respect to the allomorph -ra. It would be interesting to know the responses throughout the territory of Castilian speech in order to see if these results extend throughout or if an alternation with the -se form occurs, although it is believed that a new study, which would focus exclusively on the use of the pretérito imperfecto de subjuntivo in Spanish, would be needed.

\footnotetext{
19 "In the current state of the language the form in -ra can always be employed as an equivalent of the form in -se, and if the opposite is not possible in all the cases for the simple form cantase, the reason is none other than the conservation on the part of cantara of some indicative mood uses, remnants of its etymological value. However, as expressions of the subjunctive's own modal content, the forms in -ra and in -se are at present perfectly equivalent, with which the existence of two specific expressive occurrences must be shown in relation to allomorphism (...). The reduction in the use of one of these forms in favour of the other spoken language us, with all probability, one of the factors which have motivated in some authors a wish to see differences of a significant kind between cantara and cantase, differences which are completely imaginary according to the workings of the current Spanish verb system" (RAE 1999: 2910).
} 


\subsection{Verb tenses in the apodosis}

In contrast to what was presented beforehand regarding the protasis, the tenses employed in the apodosis do not display such a clear territorial distribution.

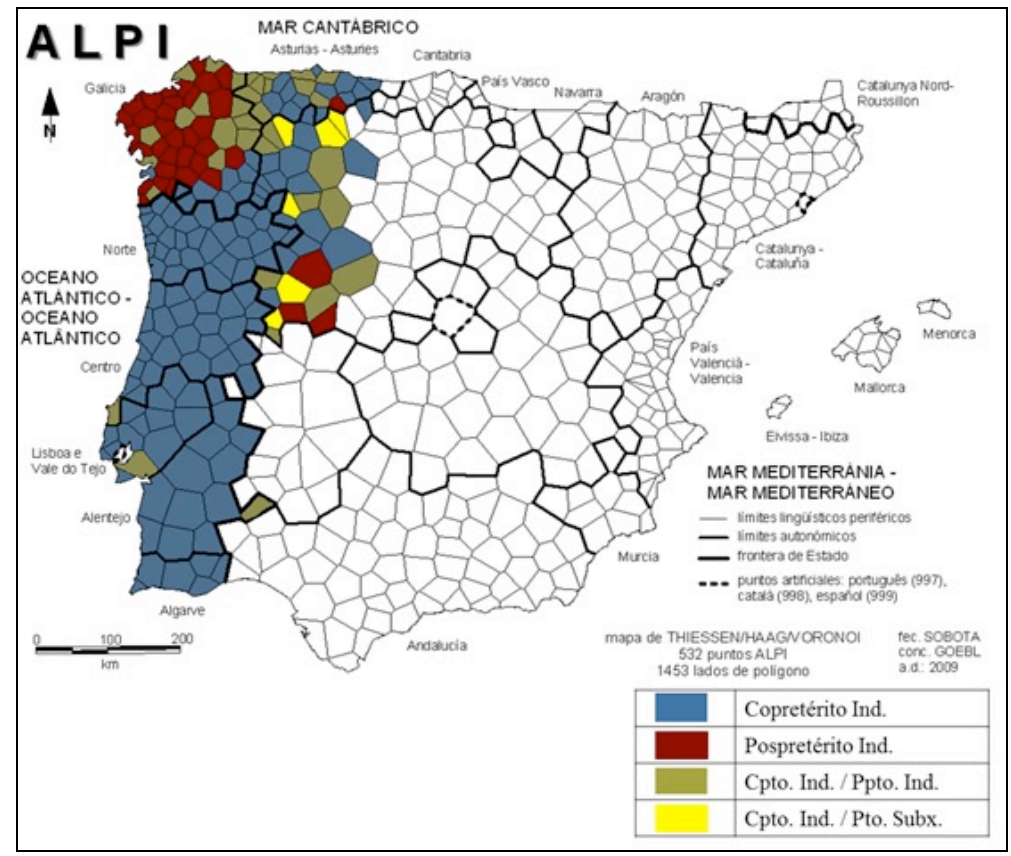

Map 2. Verb tenses in the apodosis

As can be observed on the Map 2, the majority tense is the copretérito de indicativo which extends throughout the entire Portuguese domain, the south of Galicia and a good number of Astur-Leonese locations. The employment of the pospretérito de indicativo, represented in yellow, is also common, especially in the Galician domain. However, the localities in which both tenses were registered are frequent. The data gathered in each one of the linguistic domain will now be analyzed more carefully.

\subsubsection{Galician}

In Galician two verb tenses in the apodoses of the sentences analyzed are registered: the copretérito and the pospretérito de indicativo. However, the majority option in this area is to use the pospretérito de indicativo, which is registered in 126 
Dialectologia. Special issue, V (2015), 109-140.

ISSN: 2013-2247

examples: 39 corresponding with the first question (compraria), 48 with the second (aprendería) and 39 with the third (mataría). As for the copretérito de indicativo, 57 examples of the use of this tense in these constructions were collected: 22 in the first question (compraba), 13 in the second (aprendia) and 22 in the third (mataba). In short, the pospretérito appears in $70 \%$ of the examples and the copretérito in $30 \%$.

The information extracted from the ALPI regarding the employment of these tenses in conditional sentences contrasts with Xove's contribution (1986: 133, 134):

No galego falado a presencia do Antepretérito irreal é moi cativa; o Copretérito é con moito a forma máis empregada, seguida do Pospretérito. Esta última forma, xunto co Copretérito, predomina en cambio na lingua escrita en prosa. A presencia do Antepretérito é en xeral tamén baixa neste rexistro, como na lingua falada. ${ }^{20}$

In a note, Xove shows the data that he took into account when providing this information:

Valémonos das transcripcións do material grabado por toda Galicia para o Atlas Lingüístico de Galicia ( $A L G a$ ), que suman 245 folios, e das transcripcións das grabacións correspondentes á provincia da Coruña reunidas e arquivadas no Instituto da Lingua Galega (ILGa), que fan un total de 389 folios. Nas primeiras recollemos, para toda Galicia, 82 exemplos de Copretérito irreal, 24 de Pospretérito e 6 de Apto. Nas segundas, 97, 18 e 2 respectivamente. ${ }^{21}$

Regarding the differences between the data of the $A L P I$ that have been taken into account in this study and those of the $A L G a$, examined by Xove, it can be seen that

\footnotetext{
20 "In spoken Galician the presence of the irreal Antepretérito is very limited; the Copretérito is the form most employed and by a large degree, followed by the Pospretérito. However, this final form, together with the Copretérito, prevails in the language written in prose. The presence of the Antepretérito is in general also low in this register, as in the spoken language."

${ }^{21}$ "We made us of the transcriptions of the material recorded throughout Galicia for the Linguistic Atlas of Galicia (ALGa), which totals 245 pages, and the transcriptions of the recordings corresponding to the province of A Coruña collected together and archived in the Galician Language Institute (ILGa), which make a total of 389 pages. In the first we find, for all of Galicia, 82 examples of the Copretérito irreal, 24 of the Pospretérito and 6 of the Apto. In the second, 97,18 and 2 respectively."
} 
in the approximately 40 years which separate the two atlases, ${ }^{22}$ a considerable increase occurred in the use of the copretérito and a notable decrease of the pospretérito in order to express irreality in conditional sentences, reaching the point of reversing the percentages of the use of the two tenses. However, there might be other causes of this marked difference in the uses of the copretérito and the pospretérito. In the $A L P I$ questionnaire, the tense employed in the utterances of the three sentences is the pospretérito (compraría, aprendería, mataría); it is quite possible that the interview method (direct question and sentence repetition, or the "imitation of the proposed model" to which De Benito refers) influenced the informants' responses and, as a result, the percentages cited by this study.

Regardless of the greater or lesser use, in Galician three tenses in the apodosis of the conditional sentence can be found: copretérito, pospretérito and antepretérito de indicativo, although the last of these is not very common and is not registered in the ALPI. Just as Álvarez \& Xove $(2002: 299,300)$ point out, the three tenses are variants of meaning when in the "indicativo irreal" mood, where the time values disappear: the copretérito loses its principal value of simultaneity to what precedes the origin, and the pospreterito the principal value of posteriority to what precedes the origin, in such a way that both do not possess a specific temporal value.

\subsubsection{Portuguese}

In the Portuguese domain, the pretérito imperfeito de indicativo [copretérito de indicativo] is practically the only tense registered in the apodosis of conditional sentences studies. 91 examples can be found in the first question (comprava), 90 in the second (aprendia) and 92 in the third (matava). The futuro de pretérito simples [pospretérito de indicativo] is also found in the $A L P I$, but its presence is very minority, being registered on this occasion in just three of the 92 Portuguese locations surveyed: in Atouguia da Baleia (258) it is found in the first sentence (compraria) and in Moita (276) and Barrancos (281), in the second (aprenderia).

\footnotetext{
${ }^{22}$ The collection of data by the ALPI in the Galician locations took place between 1931 and 1935 . The fieldwork for the development of the ALGa began in 1974.
} 
Dialectologia. Special issue, $\boldsymbol{V}$ (2015), 109-140.

ISSN: 2013-2247

According to Cunha \& Cintra (2000: 462), both tenses can be employed in the apodosis of the conditional sentences, but different nuances in the use of one or the other exist:

O futuro do pretérito pode ser substituído pelo imperfeito do indicativo nas afirmações condicionadas. Comparen-se as seguintes asserções:

Sem a sua interferência, eu estaria perdido.

Sem a sua interferência, eu estava perdido.

Na primeira, o facto principal (estar perdido) é apresentado como consequência provável da condição que não ocorreu; na segunda, ele aparece como o efeito imediato e inelutável dela. ${ }^{23}$

\subsubsection{Astur-Leonese}

In the Astur-Leonese domain, the tense most frequently registered in the apodosis of the conditional sentences analyzed is the pretéritu imperfeutu d'indicativu [copretérito de indicativo]. It is found in 30 responses to the first question (compraba), in 20 to the second (aprendía) and in 29 to the third (mataba); that is, approximately in $88 \%$ of total responses. The probability value which the preteritu imperfeutu d'indicativo presents in these conditional sentences is described in the Gramática de la Llingua Asturiana (ALLA 2001: 181) as a notion derived from the imperfect character of this tense:

[Pretéritu imperfeutu d'indicativo] De la noción d'aición non peracabada pue pasase a la improbabilidá, y d'aende a espresar la non realización. Por exemplu, trayíenvos los regalos nun especifica si l'aición tuvo o non un final o cumplimientu (frente a traxéronvos los regalos, onde'l cumplimientu ye efeutivu), polo que pue entendese como una realización probable (trayíenvos los regalos si pudieren,

\footnotetext{
${ }^{23}$ "The futuro do pretérito can be substituted by the imperfeito do indicativo in conditional affirmations. Compare the following assertions:

Sem a sua interferência, eu estaria perdido.

Sem a sua interferência, eu estava perdido.

In the first, the principal action (estar perdido) is presented as a probable consequence of the condition which did not occur; in the second, it appears as the immediate and ineluctable effect of it."
} 
equivaliendo al condicional trayeríenvos) o como una non realización (trayíenvos los regalos, pero nun vos los traxeron). ${ }^{24}$

It also appears in the $A L P I$, although with a much lesser frequency than that of the pretéritu imperfeutu, or condicional [pospretérito de indicativo]. It is registered once in the first and third questions: compraría and mataría, in locations 315 and 323 respectively and seven times in the second: aprendería, in locations 304, 310, 311, 313, 314,315 and 325.

Finally, the presence of the pretéritu imperfeutu de suxuntivu [preterito de subxuntivo] is very minor, registered only in three responses to the second question (aprendiera), in locations 326, 330 and 343, expressing the content of "probabilidá futura nel pasáu" which is indicated for this tense in the Gramática de la Llíngua Asturiana (ALLA 2001: 182):

[Pretéritu imperfeutu de suxuntivu] amuesa conteníos como'l de deséu (quería que lo ficiera, oxalá lo ficiera) o -equivaliendo al condicional- el de probabilidá futura futura nel pasáu (cantara una tonada si pudiera, viniera o nun viniera tábemos esperándolu). ${ }^{25}$

\subsubsection{Castilian}

In the same way as in Astur-Leonese, in the Castilian domain three tenses are also registered in the apodosis: the pretérito imperfecto de indicativo (copretérito de indicativo), the condicional simple (pospretérito) and the pretérito omperfecto de subjuntivo (pretérito de subxuntivo). The most frequent is the imperfecto de indicativo, registered in almost $60 \%$ of the total responses. The distribution by question is the

\footnotetext{
24 "[Pretéritu imperfeutu d'indicativo] It can shift from the notion of an unconsumed action to that of improbability, and from there to express the non-occurence. For example, trayíenvos los regalos does not specify whether the action had an end or fulfillment or not (as compared with a traxéronvos los regalos, where the fulfillment is effective), so that it can be regarded as a probable completion (trayíenvos los regalos si pudieren, equivalent to the conditional trayerienvos) or as an incompletion (trayíenvos los regalos, pero nun vos los traxeron)."

${ }_{25}$ "[Pretéritu imperfeutu de suxuntivu] displays contents such as desire (quería que lo ficiera, oxalá lo ficiera) or - equivalent to the conditional - that of future probability future in the past (cantara una tonada si pudiera, viniera o nun viniera tábemos esperándolu)."
} 
Dialectologia. Special issue, $\boldsymbol{V}$ (2015), 109-140.

ISSN: 2013-2247

following: 11 examples of the use of this tense were found in the first of these questions (compraba), 9 in the second (aprendía) and 17 in the third (mataba). The use of the condicional simple is also quite frequent (35\%), and is collected in 8 examples for the first question (compraría), 11 for the second (aprendería) and 3 for the third (mataría). This data extracted from the ALPI, through which a greater use of the pretérito imperfecto in the Castilian of the Peninsular Northwest can be confirmed, contrast with those recorded by E. Montolío (1999: 3667) for the context of the Castilian domain; he notes that the pattern " $<S i+$ imperfecto de subjuntivo + condicional>" is, in addition to the classic pattern of condicionais potenciais, also "la combinación modal-temporal más frecuente de dicho valor". ${ }^{26}$ However, this researcher also points out the high frequency of the imperfecto de indicativo, especially in colloquial registers:

\begin{abstract}
La aparición del imperfecto de indicativo en la apódosis de este esquema $[<\mathrm{Si}+$ imperfecto de subjuntivo + imperfecto de indicativo>] constituye un uso no normativo, pero que se encuentra notablemente extendido en registros coloquiales del español, de modo que podría considerarse un esquema propio del estándar informal (...) No parece que este esquema sustituya al estándar (imperfecto-condicional), sino que el hablante lo maneja como una variante sintáctica más a su disposición para expresar creencia en una mayor probabilidad de cumplimiento de lo propuesto en la apódosis en caso de cumplimiento de la proposición protática. ${ }^{27}$
\end{abstract}

Finally, in the $A L P I$, the pretérito imperfecto de subjuntivo: comprara is registered on four occasions in locations 353 and 357, aprendiera in 329 and matara also in 329. The use of this tense in the conditional apodosis, already infrequent by the beginning

\footnotetext{
26 "The most common modal-temporal combination of the aforementioned value."

27 "The appearance of the imperfecto de indicativo in the apodosis of this pattern $[<\mathrm{Si}+$ imperfecto de subjuntivo + imperfecto de indicativo $>$ ] contitutes not a normative use, but one which is found notably extended in colloquial registers of Spanish, in such a way that it could be considered a pattern proper of the informal standard (...). It does not seem that this pattern substitues the standard (imperfectocondicional), but that the speaker manages it as a syntatical variant more at his or her disposal for expressing belief in a greater probability of fulfillment than that proposed in the apodosis in the event of the protatic proposition being completed."
} 
of the 20th century as can be concluded from the ALPI data, is described in the Nueva gramática de la lengua española (RAE, 2009: 1807) [New Grammar of the Spanish Language] as a "característica de la lengua clásica, en la que adquiere el valor de cantaría". ${ }^{28}$ It also points out that constructions such as Me comprara un carro si tuviera dinero are now no longer employed in peninsular Castilian yet persist in the popular language of some Hispano-American countries.

\section{Conclusions}

In this study the data offered to us by $A L P I$ concerning conditional sentences in the Romance languages of the Peninsular Northwest has been analyzed. At the beginning of exposition of the results obtained, the difficulties presented by the study of syntax on the basis of a linguistic atlas were underlined, since the responses offered by the informants could be influenced by the attitude of the interviewer and by his or her manner of formulating the question. Therefore, aware that it is not an ideal corpus upon which the study of conditional sentences has been based, this analysis has attempted to proceed with caution, presenting data which is presented in the ALPI and contrasting it with that provided by the grammars from the different languages regarding these constructions.

Nevertheless, in spite of the aforementioned limitations, the results obtained reveal the existence of different conditional structures in the languages of the Pensinular Northwest; in each linguistic domain, several structures and different tenses in protasis and apodosis were registered in the ALPI. Yet in spite of the variety collected, it is also possible to observe in each language the predominance of some structures over others.

Therefore, whilst Galician reveals a preference for conditional structures formed by the copreterito de subxuntivo with the alomorph -ra in the protasis and the pospretérito de indicativo in the apodosis (tivera / estudara / puidera + compraría / aprendería / mataría), Portuguese prefers the conditional pattern composed by the

\footnotetext{
28 "Characteristic of classic language, in which it acquires the value of cantaría."
} 
copretérito de subxuntivo in the protasis and the copretérito de indicativo in the apodosis (tivesse / estudasse / pudesse + comprava / aprendia / matava). In AsturLeonese, the structure formed by the copreterito de subxuntivo in the protasis and the copretérito de indicativo in the apodosis (tuviera / estudiara / pudiera + compraba / aprendía ( mataba) is predominant. Finally, in the Castilian of the area studied, two conditional patterns alternate: on the one hand, that which combines the copretérito de subxuntivo with the alomorph -ra in the protasis and the copreterito de indicativo in the apodosis (tuviera / pudiera + compraba / mataba); on the other hand, that which combines the copretérito de subxuntivo with the alomorph -ra in the protasis with the pospretérito de indicativo in the apodosis (estudiara + aprendería). It would be interesting in future studies to extend the territory studied to the rest of the Castilian domain in order to contrast the results and therefore obtain the majority solution by taking into account the entire territory.

This preference displayed by each language for certain specific structures in order to construct conditional sentences does not impede a discussion of the common traits between the different domains studies. Thus, concerning protasis, Galician AsturLeonese and Castilian share the preference for the use of the copretérito de indicativo with the TMM -ra. Although in Galician and Castilian -se is a variant of -ra, the ALPI data reveals that -se is a minority in these languages, in contrast to what occurs in Portuguese, where it is practically the only TMM registered. In regard to the tenses of the apodosis, the copretérito and the pospretérito de Indicativo are registered in all languages. In Portuguese, the employment of the copretérito is clearly the majority; in the others, the differences in the usage percentages are not so striking, with the two tenses being registered in more locations.

\section{References}

ALLA $\left(2001^{3}\right)$ Gramática de la Llingua Asturiana, Uviéu: Academia de la Llingua Asturiana. Álvarez Blanco, Rosario \& Xosé Xove Ferreiro (2002) Gramática da lingua galega, Vigo: Galaxia. 
ALPI (1962) Atlas Lingüístico de la Península Ibérica, Madrid: C.S.I.C.

Álvarez PÉrez, Xosé Afonso (2014) “(Des-)continuidade de léxico dialectal na fronteira galegoportuguesa", in Xulio Sousa, Marta Negro Romero \& Rosario Álvarez (eds.), Lingua e identidade na fronteira galego-portuguesa, Santiago de Compostela: Consello da Cultura Galega, 171-200.

BABARRO GonZÁlEZ, Xoán (2003) Galego de Asturias: delimitación, caracterización e situación sociolingüística, A Coruña: Fundación Pedro Barrié de la Maza.

De Benito Moreno, Carlota (2010) “Las oraciones pasivas e impersonales con se: estudio sobre el ALPI", Dialectologia, 5, 1-25.

http://www.publicacions.ub.edu/revistes/dialectologia5/

CINTRA, Lindley \& Celso CUNHA $\left(2000^{16}\right)$ Nova gramática do português contemporâneo, Lisboa: Sá da Costa.

HEAP, David (2002) "Segunda noticia histórica del ALPI", Revista de Filologia Española, 82, 5-19.

Montolío, Estrella (1999) "Las construcciones condicionales", in Ignacio Bosque \& Violeta Demonte (dirs.), Gramática descriptiva de la lengua española, Madrid: Real Academia Española/Espasa Calpe, 3643-3739.

MORALA ROdRíGUeZ, José Ramón (2011) “La frontera histórica entre el Astur-Leonese y el castellano", in Ramón de Andrés Díaz (coord.), Lengua, ciencia y fronteras, Uviéu: Ediciones Trabe/Universidá d'Uviéu, 89-120.

Mouzo VILlAR, Rosa (2009) "Análise contrastiva entre galego e portugués: as oracións condicionais no ALPI", in Armanda Costa, Isabel Falé \& Pilar Barbosa (orgs.), Textos seleccionados no XXIV Encontro Internacional da Associação Portuguesa de Lingüística, Lisboa: APL.

Pedrazuela Fuentes, Mario (2005) "Nuevos documentos para la historia del ALPI", Revista de Filología Española, 85, 271-293.

RAE (1999) Gramática Descriptiva de la Lengua Española, Madrid: Espasa Calpe.

RAE (2009) Nueva Gramática de la Lengua Española, Madrid: Espasa Libros.

SECO OROSA, Ana (2001) "Determinación da fronteira lingüística entre o galego e o leonés nas provincias de León e Zamora", Revista de Filología Románica, 18, 77-102.

SOUSA FERNÁNDEZ, Xulio C. (2010) "Entre el atlas lingüístico y el diccionario. Un diccionario de léxico tradicional a partir de los materiales del ALPI", in Ignacio Ahumada (ed.), Metalexicografía variacional. Diccionarios de regionalismos y diccionarios de especialidad, Málaga: Universidad de Málaga, 237-256. 
Dialectologia. Special issue, V (2015), 109-140.

ISSN: 2013-2247

Xove FerReiro, Xosé (1986) "As formas en -ra e en -se na obra poética galega de Rosalía", in Actas do Congreso Internacional dedicado a Rosalía de Castro e o seu tempo, v. 3, Santiago de Compostela: Consello da Cultura Galega, 134-149.

Xove Ferreiro, Xosé (1992) "O verbo", in Rosario Álvarez (dir.), Estudios dedicados a Celso Emilio Ferreiro, v. 1, Santiago de Compostela: Universidade de Santiago de Compostela, 119-170.

VeIGA, Alexandre (1991) "Condicionales, concesivas y modo verbal en español", Verba, anexo 34. 


\section{Annexes}

\section{Locations of the ALPI studied}

\section{Galician domain}

\begin{tabular}{|c|c|}
\hline 100 Sismundi - A Coruña & 130 Cuntis - Pontevedra \\
\hline 101 Valdoviño - A Coruña & 131 Vilanova de Arousa - Pontevedra \\
\hline 102 Miño - A Coruña & 132 Meaño - Pontevedra \\
\hline 103 Oleiros - A Coruña & 133 Cerdedo - Pontevedra \\
\hline 104 Abegondo - A Coruña & 134 Bueu - Pontevedra \\
\hline 105 Aranga - A Coruña & 135 Fornelos de Montes - Pontevedra \\
\hline 106 Baio - A Coruña & 136 Nigrán - Pontevedra \\
\hline 107 Carballo - A Coruña & 137 Ponteareas - Pontevedra \\
\hline 108 Corcubión - A Coruña & 138 Arbo - Pontevedra \\
\hline 109 Santa Comba - A Coruña & 139 Tui - Pontevedra \\
\hline 110 Ordes - A Coruña & 140 O Rosal - Pontevedra \\
\hline 111 Boimorto - A Coruña & 141 O Irixo - Ourense \\
\hline 112 A Lavacolla - A Coruña & 142 Vilamarín - Ourense \\
\hline 112.1 Muros - A Coruña & 143 A Arnoia - Ourense \\
\hline 113 Rois - A Coruña & 144 Maceda - Ourense \\
\hline 114 Covas - Lugo & 145 Celeiros - Ourense \\
\hline 115 Muras - Lugo & 146 O Bolo - Ourense \\
\hline 116 Ferreira do Valadouro - Lugo & 147 Rubiá - Ourense \\
\hline 117 Devesa - Lugo & 148 Rairiz de Veiga - Ourense \\
\hline 118 Guitiriz - Lugo & 149 A Gudiña - Ourense \\
\hline 119 Cospeito - Lugo & 150 Entrimo - Ourense \\
\hline 120 Neiro - Lugo & 151 Oímbra - Ourense \\
\hline 121 Palas de Rei - Lugo & 300 Salgueiras - Asturias \\
\hline 122 Navia de Suarna - Lugo & 301 As Campas - Asturias \\
\hline 123 Meixente - Lugo & 302 Freal - Asturias \\
\hline 124 Pedrafita do Cebreiro - Lugo & 303 Boal - Asturias \\
\hline 125 Chantada - Lugo & 323 Cuantas - Asturias \\
\hline 126 Sober - Lugo & 324 Ponte de Rei - León \\
\hline 127 San Clodio - Lugo & 333 Castroquilame - León \\
\hline 128 Agolada - Pontevedra & 340 Padornelo - Zamora \\
\hline 129 Bandeira - Pontevedra & 341 Hermisende - Zamora \\
\hline
\end{tabular}


Dialectologia. Special issue, V (2015), 109-140.

ISSN: 2013-2247

Portuguese domain

\begin{tabular}{|c|c|}
\hline 200 Paderne - Viana do Castelo & 247 Chainça - Coimbra \\
\hline 201 Insalde - Viana do Castelo & 248 Arganil - Coimbra \\
\hline 202 Moledo - Viana do Castelo & 249 Belmonte - Castelo Branco \\
\hline 203 Portuzelo - Viana do Castelo & 250 Ourondo - Castelo Branco \\
\hline 204 Tamente - Viana do Castelo & 251 Monsanto - Castelo Branco \\
\hline 205 Salamonde - Braga & 252 Alcains - Castelo Branco \\
\hline 206 Balugães - Braga & 253 Oleiros - Castelo Branco \\
\hline 207 Marinhas - Braga & 254 Rosmaninhal - Castelo Branco \\
\hline 208 Apúlia-Braga & 255 Vieira - Leiria \\
\hline 209 Brito - Braga & 256 Pataias - Leiria \\
\hline 210 Fafe - Braga & 257 Mendiga - Leiria \\
\hline 211 Arco de Baúlhe - Braga & 258 Atouguia da Baleia - Leiria \\
\hline 212 Vila do Conde - Oporto & 259 Espite - Santarém \\
\hline 213 Santo Tirso - Oporto & 260 Ferreira do Zêzere - Santarém \\
\hline 214 Nevogilde - Oporto & 261 Lapas - Santarém \\
\hline 215 Gondar - Oporto & 262 Rio Maior - Santarém \\
\hline 216 Paço de Rei - Oporto & 263 Cartaxo - Santarém \\
\hline 217 Montalegre - Vila Real & 264 Almeirim - Santarém \\
\hline 218 Carrazedo de Montenegro - Vila Real & 265 Coruche - Santarém \\
\hline 219 Vilarinho de Samardã - Vila Real & 266 Montalvão - Portalegre \\
\hline 220 Sobreiró - Bragança & 267 Belver - Portalegre \\
\hline 221 Rio de Onor - Bragança & 268 Vale de Açor - Portalegre \\
\hline 222 Rebordãos - Bragança & 269 Reguengo - Portalegre \\
\hline 223 Torre de Dona Chama - Bragança & 270 Sousel - Portalegre \\
\hline 224 Vimioso - Bragança & 271 Campo Maior - Portalegre \\
\hline 226 Peredo - Bragança & 272 Sobreiro - Lisbon \\
\hline 227 Vilarinho das Azenhas - Bragança & 273 Povos - Lisbon \\
\hline 228 Lagoaça - Bragança & 274 Almargem - Lisbon \\
\hline 229 Vila Nova de Foz-Coa - Guarda & 275 Alcabideche - Lisbon \\
\hline 230 Quinta Nova - Guarda & 276 Moita - Setúbal \\
\hline 231 Casas de Soeiro - Guarda & 277 Santana - Setúbal \\
\hline 232 Vilar Formoso - Guarda & 278 Grândola - Setúbal \\
\hline 233 Aldeia do Bispo - Guarda & 279 São Matias - Évora \\
\hline 234 São Romão - Guarda & 280 Alandroal - Évora \\
\hline 235 São João da Pesqueira - Viseu & 281 Barrancos - Beja \\
\hline 236 Moimenta da Beira - Viseu & 282 Moura - Beja \\
\hline 237 Vale de Matos - Viseu & 283 Ferreira do Alentejo - Beja \\
\hline 238 Conlela - Viseu & 284 Vila Nova de Milfontes - Beja \\
\hline 239 Castendo - Viseu & 285 Ourique - Beja \\
\hline 240 Eiras de Castelões - Viseu & 286 Monte dos Sapos - Beja \\
\hline 241 Sobrado de Paiva - Aveiro & 287 Santa Justa - Faro \\
\hline 242 Pardilhó - Aveiro & 288 Odeleite - Faro \\
\hline 243 Famalicão - Aveiro & 289 Alte - Faro \\
\hline 244 Praia de Mira - Coimbra & 290 Marmelete - Faro \\
\hline
\end{tabular}




\begin{tabular}{|l|l|}
\hline 245 Montemor-o-Velho - Coimbra & 291 Sagres - Faro \\
\hline 246 Lavos - Coimbra & 292 Fuseta - Faro \\
\hline
\end{tabular}

\section{Astur-Leonese domain}

\begin{tabular}{|l|l|}
\hline 225 Duas Igrejas - Bragança & 318 Nozaleda - Asturias \\
\hline 304 Busmente - Asturias & 319 Pintueles - Asturias \\
\hline 305 Navelgas - Asturias & 320 Sames - Asturias \\
\hline 306 Santa Eulalia - Asturias & 321 Los Carriles - Asturias \\
\hline 307 Soto de la Barca - Asturias & 322 Cimiano - Asturias \\
\hline 308 Pola de Somiedo - Asturias & 325 Lillo de Bierzo - León \\
\hline 309 Vi!llanueva - Asturias & 326 Páramo del Sil - León \\
\hline 310 La Mata - Asturias & 327 Omañón - León \\
\hline 311 Santiago del Monte - Asturias & 328 Torrebarrio - León \\
\hline 312 San Martín de Podes - Asturias & 330 Pontedo - León \\
\hline 313 Llantones (Leorio) - Asturias & 334 Lucillo - León \\
\hline 314 Cenera - Asturias & 337 San Ciprián de Sanabria - Zamora \\
\hline 315 Felechosa - Asturias & 338 San Martín de Castañeda - Zamora \\
\hline 316 Malveda - Asturias & 339 Cubo de Benavente - Zamora \\
\hline 317 Cima la Villa (Lada) - Asturias & 343 Mahide - Zamora \\
\hline & 345 Villarino tras la Sierra - Zamora \\
\hline
\end{tabular}

\section{Castilian domain}

\begin{tabular}{|l|l|}
\hline 329 Folledo - León & 350 Gejuelo del Barro - Salamanca \\
\hline 331 Cofiñal - León & 351 Campo de Peñaranda - Salamanca \\
\hline 332 Pío - León & 352 Hinojosa del Duero - Salamanca \\
\hline 335 Laguna Dalga - León & 353 Retortillo - Salamanca \\
\hline 336 Calzada del Coto - León & 354 Aldea del Obispo - Salamanca \\
\hline 342 Otero de Bodas - Zamora & 355 Serradilla del Arroyo - Salamanca \\
\hline 344 Villafáfila - Zamora & 356 Linares de Riofrío - Salamanca \\
\hline 346 Losacio de Alba - Zamora & 357 Fuenteguinaldo - Salamanca \\
\hline 347 Fariza - Zamora & 358 El Payo - Salamanca \\
\hline 348 El Pego - Zamora & 359 Valdefuentes de Sangusín - Salamanca \\
\hline 349 Villarino (de los Aires) - Salamanca & \\
\hline
\end{tabular}


Dialectologia. Special issue, V (2015), 109-140.

ISSN: 2013-2247

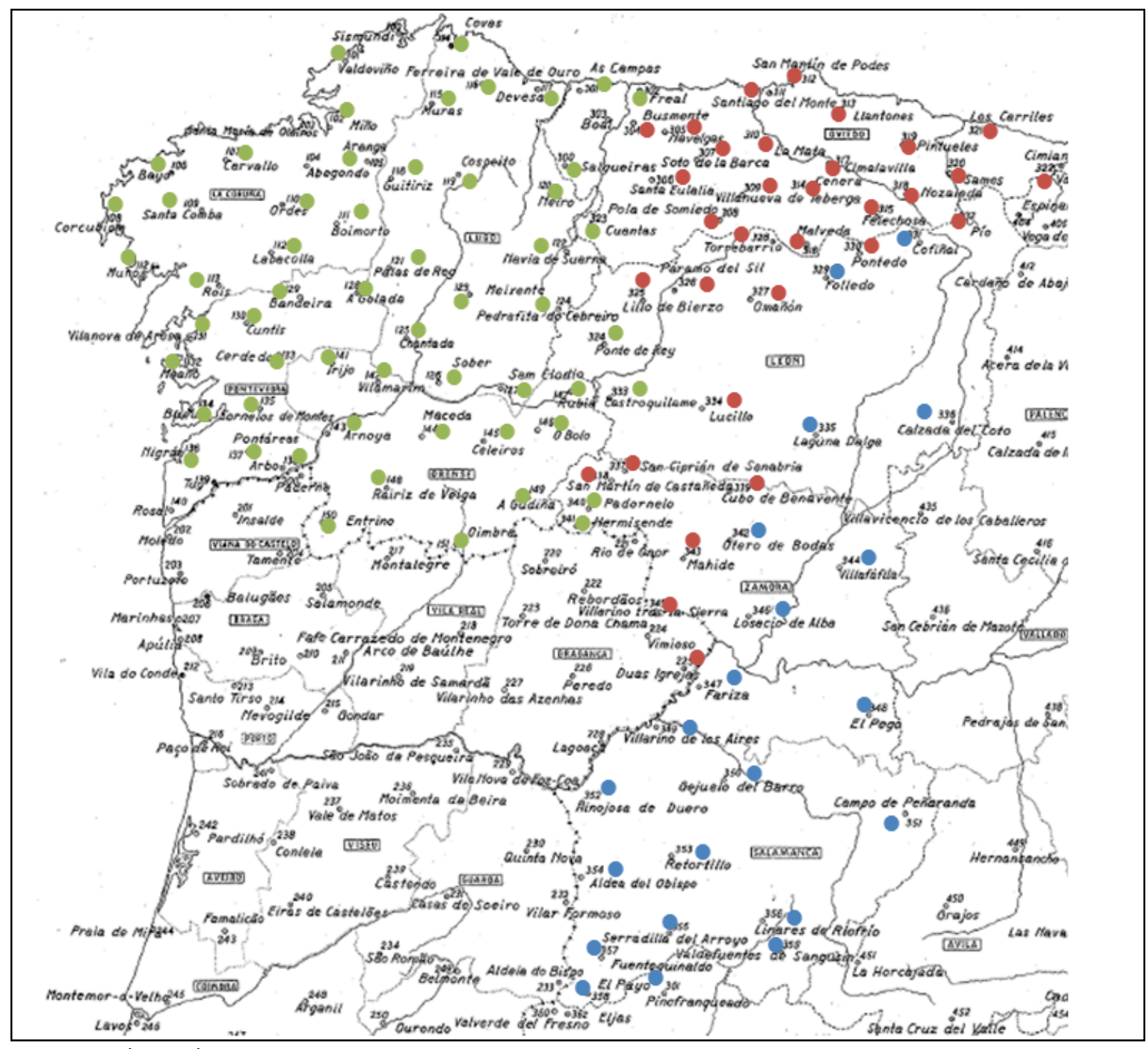

- Galician domain

- Astur-Leonese domain

- Castilian domain

Map 3. Map of linguistic domains (I) 


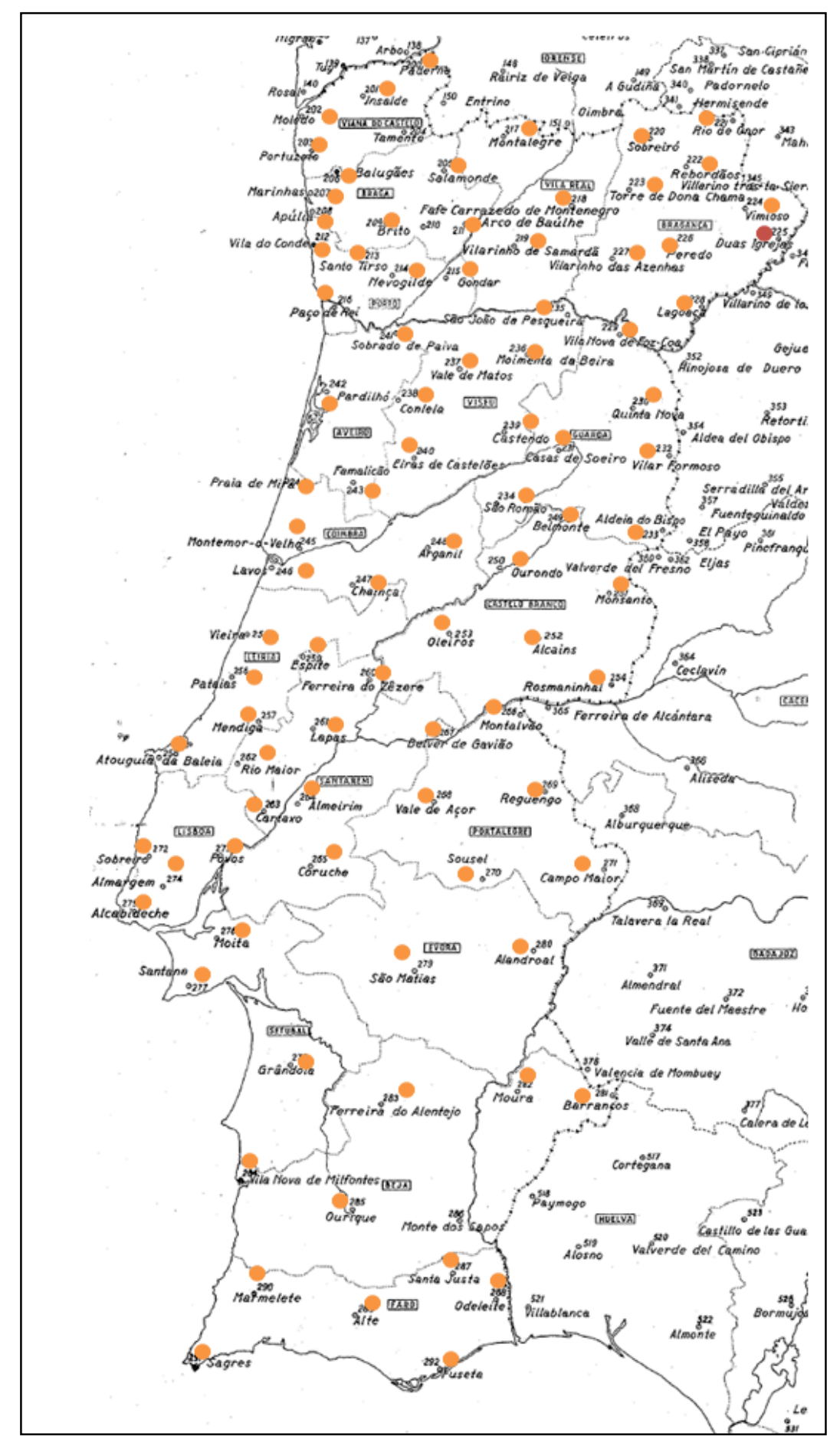

- Portuguese domain

Map 4. Map of linguistic domains (II) 